IZA DP No. 6554

Income Inequality and Health: Lessons from a Refugee Residential Assignment Program

Hans Grönqvist

Per Johansson

Susan Niknami

May 2012 


\title{
Income Inequality and Health: Lessons from a Refugee Residential Assignment Program
}

\author{
Hans Grönqvist \\ SOFI \\ Per Johansson \\ IFAU, UCLS and IZA \\ Susan Niknami \\ SOFI
}

Discussion Paper No. 6554

May 2012

IZA

P.O. Box 7240

53072 Bonn

Germany

Phone: $+49-228-3894-0$

Fax: +49-228-3894-180

E-mail: iza@iza.org

Any opinions expressed here are those of the author(s) and not those of IZA. Research published in this series may include views on policy, but the institute itself takes no institutional policy positions.

The Institute for the Study of Labor (IZA) in Bonn is a local and virtual international research center and a place of communication between science, politics and business. IZA is an independent nonprofit organization supported by Deutsche Post Foundation. The center is associated with the University of Bonn and offers a stimulating research environment through its international network, workshops and conferences, data service, project support, research visits and doctoral program. IZA engages in (i) original and internationally competitive research in all fields of labor economics, (ii) development of policy concepts, and (iii) dissemination of research results and concepts to the interested public.

IZA Discussion Papers often represent preliminary work and are circulated to encourage discussion. Citation of such a paper should account for its provisional character. A revised version may be available directly from the author. 


\section{ABSTRACT \\ Income Inequality and Health: Lessons from a Refugee Residential Assignment Program ${ }^{*}$}

This paper examines the effect of income inequality on health for a group of particularly disadvantaged individuals: refugees. Our analysis draws on longitudinal hospitalization records coupled with a settlement policy where Swedish authorities assigned newly arrived refugees to their first area of residence. The policy was implemented in a way that provides a source of plausibly random variation in initial location. The results reveal no statistically significant effect of income inequality on the risk of being hospitalized. This finding holds also for most population subgroups and when separating between different types of diagnoses. Our estimates are precise enough to rule out large effects of income inequality on health.

JEL Classification: $\quad 110, \mathrm{~J} 15$

Keywords: income inequality, immigration, quasi-experiment

Corresponding author:

Per Johansson

IFAU

Box 513

75120 Uppsala

Sweden

E-mail: per.johansson@ifau.uu.se

\footnotetext{
* The authors acknowledge financial support from NORFACE (Grönqvist), the Swedish Council for Working Life and Social Research (Grönqvist, Johansson and Niknami) and Jan Wallander and Tom Hedelius Stiftelser (Grönqvist and Niknami). Part of this work was undertaken while Grönqvist and Niknami visited CReAM at University College London. The authors are grateful to the faculty and staff, in particular Christian Dustmann, for their hospitality. The paper has benefitted from suggestions by seminar participants at UCL, IZA, SOLE 2011 (Vancouver), NORFACE Conference on "Migration: Economic Change and Social Challenges" (London), SOFI, and comments by Olof Åslund, Anders Björklund, Miles Corak, Matz Dahlberg, Christian Dustmann, Per Molander, Anders Stenberg, Eskil Wadensjö, the editor and two anonymous referees.
} 


\section{Introduction}

This paper investigates how income inequality affects health for a group of particularly disadvantaged individuals: refugees. An enormous literature in several disciplines has shown that inhabitants in areas with greater income inequality suffer from worse health and higher mortality rates (see reviews by e.g. Deaton 2003; Leigh, Jencks and Smeeding 2009; Wilkinson and Pickett 2006). The magnitude of the estimates in some of these studies is strikingly large. For instance, Lynch et al. (1998) find that the annual loss of lives from income inequality in the US is comparable to the combined loss of lives from lung cancer, diabetes, motor vehicle crashes, HIV, suicide and homicide. If valid, the results suggest that the rising levels of income inequality witnessed in many industrialized countries during the past decades (Gottschalk and Smeeding 2000) may have far reaching consequences for public health and that policies to combat inequality can bring major health benefits to society (see e.g. Wildman 2003). Since many disadvantaged minority groups live in areas characterized by high levels of income inequality they are especially exposed to these threats (Deaton and Lubotsky 2003). Even though minorities in general suffer from worse health (see e.g. Loue 1998) little is actually known about the relationship between inequality and health for these groups.

There are two theories linking income inequality to health. The first is the "strong" income inequality hypotheses which states that inequality itself matters, regardless of an individual's own income level. Several explanations have been proposed for why inequality might matter at all income levels. One is through political influence. Well off individuals are more likely to participate in political activities (Benabou 2000). In unequal societies rich individuals pay more to the government in terms of taxes than the transfers and services they receive. They may therefore support 
policies that favour less public spending. This could result in worse health care (Kawachi et al. 1997). It has also been suggested that inequality erodes social capital (i.e. interpersonal trust) and increases the social distance between people, which in turn has been posited to influence health through psychosocial stress, self-destructive behaviour and civic involvement (Kaplan et al. 1996).

The "weak" income inequality hypothesis (also called the relative deprivation hypothesis) states that what matters for health is an individual's income relative to his reference group. In this framework individuals are assumed to compare themselves to others who are more advantaged while ignoring those who are less advantaged. Being relatively more disadvantaged is believed to raise psychosocial stress and thereby adversely impact health (e.g. Wilkinson 1997; Marmot et al. 1991). There is plenty of evidence in the biological literature that links relative social status to both physical and mental health. ${ }^{1}$

As already mentioned, numerous articles have been published on the relationship between inequality and health during the past decades. These have been carefully reviewed by e.g. Deaton (2003); Judge, Mulligan and Benzeval (1998); Leigh, Jencks and Smeeding (2009); Lynch et al. (1998); and Wilkinson and Pickett (2006). Most of these studies are based on cross-country or cross-state comparisons and the general conclusion is that inequality strongly deteriorates health outcomes. ${ }^{2}$ To mention a few, Waldmann (1992) finds that greater cross-country inequality is associated with significantly higher infant mortality rates. Kaplan et al. (1996) show that US states characterized by high levels of inequality have higher mortality rates.

\footnotetext{
${ }^{1}$ Deaton (2001) and Eibner and Evans (2005) cite several studies.

${ }^{2}$ Only a handful aggregated level studies find no significant effect. One example is a study by Leigh and Jencks (2007) who show that the top decile income share does not affect population health in a panel of developed countries.
} 
Individual level studies have until recently been scarce. The reason is that there has been limited data on health outcomes at the individual level. In recent years an increasing number of health surveys have however been conducted and there are now several individual level studies on the topic. Overall, they show a weaker relationship between inequality and health than in aggregate area studies (Deaton 2003). Fiscella and Franks (1997), Lochner et al. (2001) and Soobader and Le Clere (1999) only find a small effect of income inequality on self-reported health. Mellor and Milyo (2002) are able to control for unobserved regional characteristics using panel data from the US on self-reported health. After adjusting for household income and regional level fixed effects they no longer find any evidence that inequality affects health.

Some individual level studies explicitly examine the weak income inequality hypothesis. One study of particular interestg is by Jones and Wildman (2008) who use rich data from the British Household Panel Survey to examine the effect of relative deprivation on self-reported health. A key feature of this study is that they use the longitudinal properties of the data to control for the potential influence of persistent unobserved individual confounders. They find that the observed association essentially disappears when estimating models that account for unobserved individual characteristics. ${ }^{3}$ Gerdtham and Johannesson (2004) use perhaps the richest data set up to now (Swedish register data merged to survey information) and are to the best of our knowledge the only study that has been able to discriminate between the effects of own income, relative income and income inequality. They find that mortality decreases significantly as individual income increases, but there is no evidence that relative

\footnotetext{
${ }^{3}$ Lorgelly and Lindley (2008) who also use the British Household Panel Survey document similar results.
} 
income differences or income inequality matters for mortality in Sweden. ${ }^{4}$ Gravelle and Sutton (2009) also find only weak evidence in support of the relative deprivation hypothesis. Other individual level studies document a significant positive association between relative deprivation and health but are unable to credibly control for the influence of confounders (e.g. Eibner and Evans 2005; Miller and Paxon 2006; Subramanyam et al. 2009). Mangyo and Park (2011) adopt an instrumental variables approach to correct for measurement error in their survey data and show that increased exposure to relative deprivation deteriorates self-reported health, and that this relationship is especially strong among neighbours and relatives.

There are at least three reasons to be concerned about the results in most previous studies. First, if individual health is a concave function of income, there will be a mechanical correlation at the aggregate level between inequality and health even if inequality has no effect on health (see e.g. Gravelle et al. 2002; Miller 2001). To measure the effect of inequality on health it is therefore essential to use individual level data. ${ }^{5}$ Second, in cases when individual level data actually have been used then the inequality measures often have been estimated by aggregating information contained in small sample surveys. It is likely that this approach generates measurement error, which biases the estimator downwards (Deaton 2003). This might explain why many individual level studies find a weaker relationship between income inequality and health. ${ }^{6}$ Third, the relationship between inequality and health may be spuriously driven by non-random sorting of individuals across regions. Causality could also run in the

\footnotetext{
${ }^{4}$ It is not possible for us to study relative deprivation among refugees' since all refugees were placed on social assistance during the initial period in Sweden which means that there is very little variation in own income between these individuals.

${ }^{5}$ Wagstaff and van Doorslaer (2000) provide a discussion of the advantages of individual level data.

${ }^{6}$ A further complication is that the measurement errors may not be random. This may for instance be the case when living in a high inequality area change the standards what counts as good or bad health.
} 
opposite direction if people with worse health are less able to work and therefore have lower earnings (e.g. Cutler, Lleras-Muney and Vogl 2010). Most past investigations control for potential confounders but in the absence of a controlled randomized experiment it is impossible to rule out the risk that the observed relationship is a result of omitted variables or reverse causality. No previous study has been able to convincingly address these potential concerns.

We circumvent these methodological problems using rich register data coupled with a Swedish refugee placement policy where authorities during the years 1985-1994 assigned newly arrived refugee immigrants to their first area of residence. The institutional setup generates a setting in which it is plausible to assume that initial exposure to income inequality is randomly determined conditional on a few key individual characteristics. The policy has been used in several previous studies to investigate peer and neighborhood effects among refugees (see e.g. Edin, Fredriksson and Åslund 2003; Åslund and Fredriksson 2009; Åslund et al. 2011).

Our data originate from administrative records and cover the entire Swedish population aged 16-65. The data contain the exact diagnosis on all individuals admitted to Swedish hospitals from 1987 to 2004 as well as a wide range of standard individual characteristics, income measures, and geographic identifiers. We measure income inequality at the municipal level using disposable income. We employ several measures: the Gini Coefficient; the Coefficient of Variation; the (log) 90 to 10 percentile income ratio. Sweden has a compressed income distribution but our analysis focuses on a period in which the country was hit by a significant economic recession due to a major banking crisis (see e.g. Englund 1999). The cross-municipal cross-year 
variation in our data is therefore large and its range spans the average Gini Coefficient in countries like the US and the UK. ${ }^{7}$

Our study offers several innovations over the existing literature. Most importantly, this is the first study to explicitly examine the impact of inequality on health for a minority group. This is important as exposure to high levels of inequality may help to explain why some minority groups suffer from worse health outcomes relative to the overall population.

Our study is also the first one to use a source of plausibly random variation in exposure to inequality to uncover the causal effect on health. The most convincing studies to date have instead relied on panel data to control for unobserved factors that may correlate with inequality and health (see e.g. Jones and Wildman 2008; Mellor and Milyo 2002).

Another major advantage is our data. The use of administrative registers allows us to compute accurate measures of inequality for the entire population, minimizing the risk of measurement error. To the best of our knowledge only a handful of datasets link hospital records to population registers and this is the first time such records are used to study this question. ${ }^{8}$ The fact that hospital records provide an objective measure of health removes potential biases in health self-reports. To corroborate our findings we also consider two alternative health indicators: mortality and sickness absence.

Another improvement is that we are able to study whether the potential effect of inequality differs across subgroups of the population that may be more susceptible to

\footnotetext{
${ }^{7}$ In the late 2000s, for instance, the Gini Coefficient in the US and the UK was about .36 and .34, respectively (OECD 2011). The Gini Coefficient in our data varies between .19 and .50 and the within municipality variation in inequality amounts to about 40 percent of the overall variation.

${ }^{8}$ Grönqvist (2009) uses similar data to study the effect of segregation on health.
} 
negative health influences. We are especially interested in investigating groups that differ in terms of education, gender and age. Due to sample size restrictions and lack of individual level data only few previous studies have been able to explore this question.

Our study also departs from the previous literature in that we consider the consequences of long-term exposure to income inequality. Even though many of the theoretical foundations of the income inequality hypothesis seem to be more applicable for long-term exposure the focus in the previous literature has been on the contemporary effect of inequality on health. We examine this issue by constructing measures of an individual's average exposure to inequality over multiple years and then instrumenting for this variable using the level of inequality in the assigned area of residence.

Our results suggest that a one standard deviation increase in any of our inequality measures raises the probability of being hospitalized by between 1.4 and 2.5 percent. This estimate corresponds to between $1 / 250$ and $1 / 20$ of the health gap between individuals with compulsory education versus university education. Although these estimates are not statistically significant they are precise enough to discard that a one standard deviation increase in inequality raises the probability of being admitted to hospital by more than between 2.1 and 8.7 percent (between $1 / 15$ and $1 / 4$ of the educational health gap). In most subgroups there is no evidence that inequality affects the risk of being hospitalized. These conclusion does not change when we instead consider long-term exposure to inequality or when we separate between different types of diagnoses. There is however some weak evidence of a significant adverse effect on older persons' health; but the magnitude of the effect is not large and it is not significant when using alternative health indicators. Our results are robust to several sensitivity 
checks including other measures of health, other income concepts, and other geographic units of analysis.

In thinking about the population to which our findings may generalize, it is important to note that our sample is very socioeconomically disadvantaged. Sweden actually has one of the largest immigrant-native differentials in the labor market among the OECD countries, and particularly refugees suffer from substantially higher rates of unemployment and welfare dependency, poor educational attainment and low incomes

(e.g. OECD 2007; Lundh et al. 2002). As the theory teaches us that less affluent groups are likely to respond stronger to exposure to a given level of inequality it suggests that any effects of income inequality on health may in fact more easily be detected in this sample. On the other hand, although our results suggest otherwise, we cannot rule out the risk that the level of inequality that the refugees faced when entering Sweden was too small relative to the level of inequality they experienced in the country of origin, or that refugees to a lesser degree do not compare themselves to other members of the local community. These are issues important to keep in mind when assessing the scope of extending our results to other populations.

The paper unfolds as follows. Section 2 explains the institutional background surrounding the placement policy and the Swedish health care system. Section 3 describes our data and empirical strategy. Section 4 contains the results and Section 5 concluding remarks.

\section{Institutional background}

This section discusses institutional facts surrounding the settlement policy. We also briefly outline the Swedish health care system. 


\subsection{Migration to Sweden and the settlement policy ${ }^{9}$}

Sweden has a relatively large share of immigrants: about 14 percent of its 9 million residents are foreign-born. Since the late 1970s the majority of the immigrants arriving are either refugees or family related immigrants. Over the past decades, the relative economic performance of the immigrants has been trending downwards. There are now large disparities in labor market outcomes between immigrants and natives (OECD 2007). There is also a significant health gap between immigrants and natives. For instance, our own estimations reveal that the probability of being hospitalized was in 1994 almost 9 percent higher among refugee immigrants than among the entire Swedish population.

As a way of reducing a strong geographic concentration of immigrants, the Swedish government enacted in 1985 a policy to assign newly arrived refugees to an initial municipality of residence. Because of the large inflow of refugees in the late 1980s, the number of receiving municipalities was increased from 60 to include 277 of Sweden's 284 municipalities in 1989. The explicit goal was that the number of refugees assigned to each municipality should constitute 2.9 per mille of the overall population (Borevi and Myrberg 2010). The policy encompassed all refugees who arrived during the period 1985-1994, except for family reunification immigrants.

Following arrival, refugees were placed in refugee centres, while waiting for the Immigration Board's ruling on whether or not to grant a residence permit. The centres were distributed all over Sweden and there was no link between the port of entry to Sweden and the location of the centre. In general, it took between three and twelve

\footnotetext{
${ }^{9}$ This section draws heavily on Åslund et al. (2011).
} 
months to be approved. Upon admission, municipal placement usually occurred immediately by the placement officers at the Immigration Board. A family was in this process treated as a single unit. The original idea was to place people in locations with good opportunities for work and education. However, since the housing market was booming during this period it became very difficult to find housing. The placement officers therefore placed refugees in municipalities with available housing. Refugees were allowed to move if they found housing in another location but were still required to take part in an 18-month introduction program in their assigned municipality. During the introduction period the refugees received social assistance. Eight years after arrival about 50 percent were still living in their assigned municipality. ${ }^{10}$ The dispersal policy was later abolished in 1994 due to a large increase in the number of refugees. In section 3.2 we discuss the arguments for why the placement policy provides exogenous variation in initial location.

\subsection{The Swedish health care system ${ }^{11}$}

The county councils are the major financiers and providers of Swedish health care.

There are 21 county councils and each council is obliged to provide its residents with equal access to health services and medical care. Health care is mostly financed through local taxes. Each county council sets its own patient fees but a national ceiling limits the total amount that a patient pays during a 12-month period (out-of-pocket). Thus, patient fees only account for about 3 percent of the total revenues. The daily fee for staying at a hospital is about USD 15. There is free choice of provider but referral is required in some cases, particularly when patients seek specialized care, or when they choose health

\footnotetext{
${ }^{10}$ Males and younger individuals were more likely to move. In general, those who moved tended to go to larger urban areas.

${ }^{11}$ This brief outline of the Swedish health care system draws on the Swedish Association of Local Authorities and Regions (2005).
} 
care in another county. The county councils are allowed to contract private providers but the majority of the health care is performed by public agents. In their contacts with health care providers immigrants are entitled to an interpreter free of charge.

\section{Data and empirical strategy}

\subsection{Data and sample selection}

Our empirical analysis exploits micro data originating from administrative registers. The dataset, collected and maintained by Statistics Sweden, covers the entire Swedish population aged 16-65 during the period 1987-2000 and individuals aged 16-74 during the period 2001-2004. It contains annual information on a wide range of educational and demographic characteristics as well as different income sources.

Information on hospitalizations was provided by the National Board of Health and Welfare and covers all inpatient medical contacts at public hospitals from 1987 through 1996. This is no major restriction since virtually all medical care in Sweden at that time was performed by public agents. From 1997 and onwards the register also includes privately operated health care. In order for an individual to be registered with a diagnosis (s)he must have been admitted to a hospital. As a general rule, this means that the person has to spend the night at the hospital. However, starting in 2002 the registers also cover outpatient medical contacts in specialized care.

An important feature of the data is that it contains the cause of each admission. The diagnoses, made by physicians, are classified according to the World Health Organization's International Statistical Classification of Diseases and Related Health Problems (ICD). ICD is a four digit coding of diseases and signs, symptoms, abnormal 
findings, complaints, and external causes of injury or diseases. ${ }^{12}$ In our analysis we focus on several common diseases: ischemic heart disease, respiratory diseases, cancer, mental health problems and diabetes. Table A.1. outlines the different types of diagnoses and the way they have been constructed. The data include possible comorbidities but we only use the main diagnosis in our analysis.

Income is measured using disposable income (in 1990 year's prices), i.e. the universe of net income from work and capital combined with net social benefits and transfers. The unit of analysis is the individual. ${ }^{13}$ We compute inequality using disposable income for the entire Swedish population aged 25-65 employing three distinct measures: (i) the Gini Coefficient; (ii) the Coefficient of Variation; (iii) the (log) 90 to 10 percentile income ratio. These measures represent some of the most commonly used ways to quantify inequality (e.g. Atkinson 1970). The Gini coefficient varies between 0 (complete equality) and 1 (complete inequality). It has several attractive properties one of which is that it is sensitive to income disparities throughout the distribution. The coefficient of variation is simply the standard deviation divided by the mean. Also this measure incorporates all data throughout the distribution. Although each measure has its shortcomings together they should well portray income inequality. We compute the variables for each municipality and year. ${ }^{14}$ As discussed by Deaton (2003), in doing so we implicitly assume that people only compare themselves with individuals living in the same municipality. Even though alternative reference groups have been suggested (e.g. age, race or education as in Eibner and Evans 2005) the

\footnotetext{
${ }^{12}$ The underreporting conditional on having been in contact with health care providers is very low and estimated to be less than one percent each year.

${ }^{13}$ An alternative solution is to use household income. However, we cannot observe co-habitants in the data if the co-habiting couple does not have any children in common. Since co-habiting is frequent in Sweden this strategy would introduce measurement error. Moreover, using the individual as the unit of analysis is not as restrictive in Sweden as it may be in other countries because of the high female labor force participation rate and the fact that Sweden applies individual based income taxation.

${ }^{14}$ The average municipality hosts about 30,000 inhabitants.
} 
standard approach in the literature is to use geographically constrained groups. ${ }^{15}$ Table A.2 displays descriptive statistics for our inequality measures and other selected variables.

We extract all immigrants aged 25-60 who arrived from a refugee sending country between 1990 and $1994 .{ }^{16}$ Small countries have been aggregated due to confidentiality rules. In total, refugees from 16 country groups are included in our analysis. The rationale for starting our analysis in 1990 is that this is when information on disposable income first becomes available. We exclude individuals with a spouse, child or parent already living in Sweden at the time of immigration as family reunification immigrants were exempted from the placement policy.

While our data provide an objective measure of health that is not plagued by self-report bias or measurement error, one potential problem is that we only have information on health for individuals who have been hospitalized. First of all, this means that our analysis less likely extends to less severe morbidities. Potentially more serious is however that the likelihood of being admitted to hospital, conditional on health, may be correlated with local income inequality. This is true if doctors in municipalities with greater income inequality are less/more likely to admit patients, or if the inhabitants are less/more likely to seek medical care. In this case our estimator may be biased. ${ }^{17}$ In section 4.2 we discuss how we deal with this issue.

\footnotetext{
${ }^{15}$ One alternative would be to measure inequality within municipalities across ethnic groups (see e.g. Bertrand, Luttmer and Mullainathan 2000 and Edin, Fredriksson and Åslund 2003). However, for small source countries this would mean that our analysis relies on very few observations and that our measures of inequality therefore are noisy.

${ }^{16}$ The placement policy was most strictly enforced in the period 1987 to 1991 . In a sensitivity analysis we excluded cohorts who arrived after 1991 (results are available on request). Although the statistical precision decreases due to the smaller number of observations it is reassuring to find that the estimates are relatively stable and do not alter the conclusions in this paper.

${ }^{17}$ This can of course also be a problem in studies using data on self-reported health status if greater inequality for instance generates higher stress levels and thereby decreases an individual's possibilities to
} 


\subsection{Using the settlement policy to identify the effect of inequality on health}

To estimate the effect of income inequality on health we exploit the Swedish refugee placement policy where authorities assigned newly arrived refugees to their first location of residence. The policy has been carefully documented elsewhere and has been used to examine the impact of neighborhood conditions on refugees' socioeconomic outcomes (see e.g. Edin, Fredriksson and Åslund 2003; Åslund and Fredriksson 2009, Åslund and Rooth 2007; Åslund et al. 2011). We refer to these studies for a more comprehensive treatment of the policy.

As previously mentioned, the institutional arrangement implied that refugees were to be assigned their initial municipality of residence. Past studies provide convincing evidence that the policy actually created a geographic distribution that was independent of unobserved individual characteristics. For instance, Edin, Fredriksson and Åslund (2003) show that the residential area of those placed clearly differed from the location choices made by immigrants arriving from the same regions shortly before the reform.

Despite this evidence it is important to note that placement officers may have tried to match refugees to specific locations. Another issue is that refugees could state residential preferences. There are three arguments for why it still is possible to consider initial location as exogenous with respect to the unobserved characteristics of the individual. First, there was no direct interaction between the placement officers and refugees. The only information on the refugee that was available to the officer was age, education, gender, marital status, family size and country of origin. The officer may

correctly assess his or her health. The direction of the bias is ambiguous and depends on the correlation between true health, observed health, and inequality. 
have tried to match individuals to their initial location based on these characteristics. However, since the administrative registers contain the same set of information we are able to control for this potential selection. Second, few refugees stated location preferences and among those who did the housing market boom further restricted residential preferences from being satisfied (see e.g. Fredriksson and Åslund 2009). Finally, the timing of the receipt of the residence permit must have coincided fully with the arrival of a housing vacancy in the preferred location in order for preferences to be fulfilled. Since placement occurred rapidly after having received the permit the joint probability of these two events to occur at the same time is extremely low. ${ }^{18}$

It is difficult to test for random assignment since it requires a variable that was not observed by the officer (or at least unexploited). Instead we provide results which illustrate the differences in how well individual characteristics predict properties of the local area in the year of arrival and then five years later. During this period individuals will have had time to change residential area. Consequently, one would expect to find a stronger link between individual and municipality characteristics five years after placement. Table 1 presents estimates from regressions where the dependent variable is some feature of the municipality measured in the year of arrival and then five years later. When looking at the results for year of arrival displayed in Panel A we find only 4 out of 48 estimates significant at the 5 percent level. This is just slightly more than what we would expect to find by pure chance. When municipality characteristics instead are observed five years after placement, we can see that 23 out of the 48 estimates are significant. This indicates that individuals over time tended to sort across municipalities.

\footnotetext{
${ }^{18}$ Oreopoulos (2003) use a similar argument when studying the effect of neighborhoods on adult outcomes for individuals who were assigned to different housing projects in Toronto.
} 
These results clearly highlight the importance of accounting for non-random selection to uncover the causal effect of income inequality on health. ${ }^{19}$

To take advantage of the plausibly exogenous variation in initial inequality created by the policy we run regressions of following form by type of diagnosis

(1) Hospitalized $_{i k j t}=\alpha+\beta$ Inequality $_{k t}+\gamma^{\prime} \mathrm{X}_{\mathrm{i}}+\delta^{\prime} \mathrm{Z}_{\mathrm{kt}}+$ origin $_{j}+$ muni $_{k}+$ year ${ }_{t}+\varepsilon_{i k j t}$

where $i$ denotes individual, $k$ municipality, $j$ region of origin, and $t$ year of arrival. $\mathrm{X}_{\mathrm{i}}$ is a vector of individual characteristics. It includes disposable income, number of children and dummies for age, gender, marital status and educational attainment (six levels). $\mathrm{Z}_{\mathrm{kt}}$ represents a vector of time-varying municipality characteristics controlling for (the log of) population size, share university educated, and the unemployment rate. origin denotes region of origin fixed effects. muni $_{k}$ represents municipality fixed effects. This vector absorbs all persistent municipal characteristics that may be related to health; e.g. access to fitness centers or environmental characteristics of the area. year ${ }_{t}$ is a vector of year of arrival fixed effects. $\varepsilon_{\mathrm{ikt}}$ is the error which by assumption is conditionally independent of the covariates in the regression model. We however allow them to be correlated across individuals in the same municipality. We estimate models where the outcome is a dummy equal to one if the individual has been hospitalized at least once during a five year period after arrival. To ensure that our inequality measures are not plagued by non-random residential mobility they are dated in the year of immigration.

\footnotetext{
${ }^{19}$ These regressions are, admittedly, non-standard as it includes municipal variables as the regressand and individual variables as regressors. The regressions are however appropriate for testing for sorting in the same spirit as using auxiliary regressions when performing Lagrange multiplier tests (see e.g. Wooldridge, 2010, p. 424).
} 
Table 1 OLS estimates from balancing tests regressing initial and later municipal properties on individual characteristics

\begin{tabular}{|c|c|c|c|c|c|c|}
\hline & \multicolumn{6}{|c|}{ "Dependent variable } \\
\hline & $\begin{array}{l}\text { Gini } \\
\text { (1) }\end{array}$ & $\begin{array}{l}\mathrm{CV} \\
\text { (2) }\end{array}$ & $\begin{array}{c}\log \\
\text { (P90/P10) } \\
(3)\end{array}$ & $\begin{array}{c}\log (\text { Pop. } \\
\text { size) } \\
(4)\end{array}$ & $\begin{array}{l}\log (\text { Unem. } \\
\text { rate } \\
(5)\end{array}$ & $\begin{array}{c}\log \text { (Univ. } \\
\text { share) } \\
(6)\end{array}$ \\
\hline & \multicolumn{6}{|c|}{ A. Year of arrival } \\
\hline Age at & .002 & .035 & .003 & .008 & .031 & .002 \\
\hline immigration $* 10^{3}$ & $(.004)$ & $(.131)$ & $(.018)$ & $(.009)$ & $(.038)$ & $(.009)$ \\
\hline \multirow[t]{2}{*}{ Female $* 10^{3}$} & -.052 & -.088 & $-.420 *$ & $-.261 *$ & -.450 & .117 \\
\hline & $(.047)$ & $(.165)$ & $(.210)$ & $(.102)$ & $(.395)$ & (.109) \\
\hline \multirow[t]{2}{*}{ Married $* 10^{3}$} & -.183 & -1.880 & -.771 & -.206 & .720 & .243 \\
\hline & $(.176)$ & $(3.730)$ & $(.945)$ & $(.273)$ & $(.916)$ & $(.201)$ \\
\hline Number of & .001 & 1.140 & .024 & $-.199 *$ & -.601 & -.049 \\
\hline children $* 10^{3}$ & $(.039)$ & $(1.710)$ & $(.200)$ & $(.088)$ & $(.325)$ & $(.071)$ \\
\hline \multicolumn{7}{|l|}{$\begin{array}{l}\text { Ref. Compulsory } \\
\text { school }\end{array}$} \\
\hline At most two years & .382 & $10.50 *$ & 1.190 & .567 & 1.410 & .286 \\
\hline high school $* 10^{3}$ & $(.196)$ & $(4.84)$ & $(.832)$ & $(.352)$ & $(1.070)$ & $(.217)$ \\
\hline At least three & .161 & .353 & .426 & .400 & .605 & .223 \\
\hline $\begin{array}{l}\text { years high } \\
\text { school*10 }\end{array}$ & $(.127)$ & $(3.88)$ & $(.577)$ & $(.226)$ & $(.954)$ & $(.176)$ \\
\hline At most two years & .237 & 5.550 & .403 & .192 & 1.420 & -.014 \\
\hline university* $10^{3}$ & $(.142)$ & $(4.530)$ & $(.658)$ & $(.301)$ & $(.903)$ & $(.202)$ \\
\hline \multirow{3}{*}{$\begin{array}{l}\text { At least three } \\
\text { years } \\
\text { university*10 }\end{array}$} & .169 & -.513 & .413 & .313 & -.318 & .192 \\
\hline & $(.112)$ & $(3.680)$ & $(.496)$ & $(.197)$ & $(.874)$ & $(.185)$ \\
\hline & \multicolumn{6}{|c|}{ B. Five years after arrival } \\
\hline Age at & -.024 & -1.050 & -.032 & 1.030 & $.493 *$ & .146 \\
\hline immigration $* 10^{3}$ & $(.030)$ & $(.997)$ & $(.112)$ & $(.927)$ & $(.111)$ & $(.177)$ \\
\hline \multirow[t]{2}{*}{ Female $* 10^{3}$} & -.294 & -7.220 & -1.210 & -12.400 & $-1.750^{*}$ & $3.900 *$ \\
\hline & $(.261)$ & $(7.990)$ & $(1.060)$ & $(10.200)$ & $(.950)$ & $(1.870)$ \\
\hline \multirow[t]{2}{*}{ Married $* 10^{3}$} & -.754 & -6.080 & $-4.880 *$ & $-41.90 *$ & $-8.000 *$ & $-6.700 *$ \\
\hline & $(.403)$ & $(14.100)$ & $(1.650)$ & $(15.70)$ & $(2.340)$ & $(3.310)$ \\
\hline Number of & $-.431 *$ & $-13.20^{*}$ & -.984 & $-15.00^{*}$ & $1.560 *$ & $-3.810^{*}$ \\
\hline children $* 10^{3}$ & $(.135)$ & $(4.010)$ & $(.637)$ & $(5.320)$ & $(.785)$ & $(1.170)$ \\
\hline $\begin{array}{l}\text { Ref. Compulsory } \\
\text { school }\end{array}$ & & & & & & \\
\hline At most two years & -.980 & -2.060 & $-4.490 *$ & -26.50 & -1.720 & $-10.90 *$ \\
\hline high school $* 10^{3}$ & $(.640)$ & $(20.300)$ & $(2.590)$ & $(22.20)$ & $(2.440)$ & $(4.820)$ \\
\hline At least three & .637 & 2.820 & 2.790 & 23.40 & -1.290 & $10.70 *$ \\
\hline $\begin{array}{l}\text { years high } \\
\text { school } * 10^{3}\end{array}$ & $(.524)$ & $(16.900)$ & $(2.160)$ & $(18.70)$ & $(2.060)$ & $(3.710)$ \\
\hline At most two years & $1.070 *$ & 12.700 & $4.700 *$ & $52.40 *$ & .747 & $24.00 *$ \\
\hline university $* 10^{3}$ & $(.488)$ & $(15.800)$ & $(2.000)$ & $(17.80)$ & $(2.380)$ & $(4.29)$ \\
\hline At least three & $2.190 *$ & 7.017 & $9.280 *$ & $77.10 *$ & 1.480 & $36.00 *$ \\
\hline $\begin{array}{l}\text { years } \\
\text { university*10 }\end{array}$ & $(.480)$ & $(14.900)$ & $(2.170)$ & $(18.00)$ & $(2.580)$ & $(5.49)$ \\
\hline
\end{tabular}

Notes: Each column represents a separate regression. All coefficients and its standard errors have been multiplied by $10^{3}$. The sample consists of refugees aged 25-60 at arrival who immigrated 1990-1994 $(\mathrm{N}=65,595)$. All regressions control for municipality, year of arrival and ethnic group fixed effects. Standard errors are clustered at the municipality level in parentheses. $*=$ significant at $5 \%$ level 


\section{Empirical analysis}

\subsection{Main results}

This section provides the results from our empirical analysis. Our baseline specification, given by equation (1), relates the probability of being hospitalized at least once in five years following arrival to inequality in the assigned municipality. Throughout, estimates are reported for all three inequality measures: the Gini Coefficient; the Coefficient of Variation; the (log) 90 to 10 income percentile ratio. To conserve space we suppress the estimates of the control variables (available upon request). In general, these estimates show a reduced risk of hospitalization for highly educated individuals, as well as for individuals with more children, married people, younger individuals, and males. As unobserved local factors are quite stable within municipalities over time we estimate the standard errors by clustering at the municipality level (Bertrand, Duflo and Mullainathan 2004).

Table 2 presents our main results. Numbers in brackets provide the percentage effect of a one standard deviation increase in inequality on the probability of being hospitalized. Estimates are shown for all individuals in our sample (Panel A) and by population subgroup (Panels B to D). We focus on groups defined by highest completed level of education, gender and age at immigration.

In Panel A we can see that there is no statistically significant effect of inequality on the probability of being hospitalized for any of our inequality measures. The point estimate in column (1) suggests that a one standard deviation increase in the Gini Coefficient (.031) raises the probability of being hospitalized in five years after arrival by .5 percentage points $(.221 \times .031)$. In relation to the mean of the dependent variable this translates into an increase in the order of 2.4 percent $((.221 \times .031) / .282)$. 
The estimate in column (2) suggests that a similar increase in the Coefficient of Variation raises the likelihood of being admitted to hospital by .004 percentage points (.001×.387), which is close to 1.4 percent. The corresponding numbers for the (log) 90 to 10 percentile income ratio are .07 percentage points $(.049 \times .142)$ and 2.5 percent.

To interpret the magnitude of these estimates it is useful to compare them to the educational health gap. The educational gradient in health has been documented in many different countries and contexts (see e.g. Cutler and Lleras-Muney 2010). In our sample individuals who have completed at least two years of university education are 9.5 percentage points less likely to be admitted to hospital in five years after arrival compared to individuals that at most have finished compulsory school. Our estimates therefore suggest that a one standard deviation increase in our inequality measures corresponds to only between $1 / 250$ and $1 / 20$ of the educational health gap.

Although not statistically significant, the estimates are precise enough for us to be able to rule out large effects. The upper limit of the 95 percent confidence interval for each of our inequality measures is: $.701, .015$ and .167 . This suggests that a one standard deviation increase in inequality raises the probability of being hospitalized by at most between 2.1 and 8.7 percent. This constitutes between $1 / 15$ and $1 / 4$ of the educational health gap. 
Table 2 OLS estimates of the effect of initial inequality on the probability of being hospitalized in five years after arrival

\begin{tabular}{|c|c|c|c|}
\hline & \multicolumn{3}{|c|}{ Inequality measure } \\
\hline Sample & $\begin{array}{l}\text { Gini } \\
\text { (1) }\end{array}$ & $\begin{array}{l}\text { CV } \\
\text { (2) }\end{array}$ & $\begin{array}{c}\log (\mathrm{P} 90 / \\
\mathrm{P} 10) \\
\text { (3) }\end{array}$ \\
\hline $\begin{array}{l}\text { A. Total sample } \\
(\mathrm{N}=65,595 ; \text { Outcome mean .282) }\end{array}$ & $\begin{array}{c}.221 \\
(.245) \\
{[2.4 \%]}\end{array}$ & $\begin{array}{c}.001 \\
(.007) \\
{[1.4 \%]}\end{array}$ & $\begin{array}{c}.049 \\
(.060) \\
{[2.5 \%]}\end{array}$ \\
\hline \multicolumn{4}{|l|}{ B. Education } \\
\hline University ( $\mathrm{N}=17,988$; Outcome mean .244) & $\begin{array}{c}.145 \\
(.501) \\
{[1.8 \%]}\end{array}$ & $\begin{array}{c}.001 \\
(.016) \\
{[1.6 \%]}\end{array}$ & $\begin{array}{c}.089 \\
(.108) \\
{[5.2 \%]}\end{array}$ \\
\hline $\begin{array}{l}\text { High school or less }(\mathrm{N}=47,607 \text {; Outcome mean } \\
.297)\end{array}$ & $\begin{array}{c}.221 \\
(.281) \\
{[2.3 \%]}\end{array}$ & $\begin{array}{c}.001 \\
(.007) \\
{[1.3 \%]}\end{array}$ & $\begin{array}{c}.037 \\
(.066) \\
{[1.8 \%]}\end{array}$ \\
\hline \multicolumn{4}{|l|}{ C. Gender } \\
\hline Females $(\mathrm{N}=30,567$; Outcome mean .315) & $\begin{array}{l}.094 \\
(.392) \\
{[.9 \%]}\end{array}$ & $\begin{array}{c}-.007 \\
(.010) \\
{[-.09 \%]}\end{array}$ & $\begin{array}{c}.094 \\
(.082) \\
{[4.2 \%]}\end{array}$ \\
\hline Males $(\mathrm{N}=35,028$; Outcome mean .254) & $\begin{array}{c}.304 \\
(.301) \\
{[3.7 \%]}\end{array}$ & $\begin{array}{c}.007 \\
(.010) \\
{[1.1 \%]}\end{array}$ & $\begin{array}{l}.009 \\
(.075) \\
{[.5 \%]}\end{array}$ \\
\hline \multicolumn{4}{|l|}{ D. Age at immigration } \\
\hline Less than $40(\mathrm{~N}=47,784$; Outcome mean .259$)$ & $\begin{array}{c}-.024 \\
(.259) \\
{[-.2 .4 \%]}\end{array}$ & $\begin{array}{c}-.006 \\
(.009) \\
{[-.09 \%]}\end{array}$ & $\begin{array}{l}-.016 \\
(.068) \\
{[-.9 \%]}\end{array}$ \\
\hline At least $40(\mathrm{~N}=17,811$; Outcome mean .344) & $\begin{array}{l}.992 * \\
(.531) \\
{[8.9 \%]}\end{array}$ & $\begin{array}{c}.026 \\
(.017) \\
{[2.9 \%]}\end{array}$ & $\begin{array}{l}.219 * * \\
(.110) \\
{[9 \%]}\end{array}$ \\
\hline Municipality FE:s & Yes & Yes & Yes \\
\hline Contry of origin FE:s & Yes & Yes & Yes \\
\hline Year of arrival FE:s & Yes & Yes & Yes \\
\hline
\end{tabular}

Notes: Each cell represents a separate regression. Inequality is measured at the (initial) municipality level using disposable income. The sample consists of refugees aged 25-60 at arrival who immigrated 1990-1994. The regressions control with dummies for: age at immigration, educational attainment (five levels), gender, marital status, missing values, and linearly for: disposable income (and its square) and family size. The regressions include municipality level controls for the unemployment rate, population size, and share of university educated; all entered in logs. Standard errors clustered at the municipality level in parentheses. $* *=$ significant at $5 \%$ level; $*=$ significant at $10 \%$ level.

It is also helpful to contrast our inequality measures to comparable measures for other less egalitarian countries. Miller (2001) reports that the between state standard deviation of the Gini coefficient in the US in 1995 was .025 . The between municipality standard deviation of the Gini coefficient in our data is .026. In other words, even though the level of inequality is much higher in the US, the cross-regional variation is 
about the same. This means that applying the US numbers when evaluating the size of the estimates will actually produce similar effects. ${ }^{20}$

Before proceeding with the analysis it is again worth mentioning that we study a minority group that faces a considerable economic disadvantage. ${ }^{21}$ This is important as the theory suggests that any detrimental health effects are likely to be more pronounced for the least well of in society. Recall that the refugees in our sample were required to take part in an introductory program for 18 months during which time they received social assistance. It is however possible to investigate whether the effect is stronger for individuals with lower income potential as proxied by low education. Panel B displays estimates by highest completed level of education. We find no statistically significant effect of inequality on the probability of being hospitalized for individuals who at most have completed high school. Neither is there a significant effect for individuals with university education. As for the total sample, the estimates are quite precise which makes it possible to rule out large effects.

Panel C shows results by gender. As we can see, there are no indications either for men or women that income inequality affects the probability of being hospitalized in five years after arrival.

In Panel D we split the sample by age at immigration using 40 as cut-off. Since youths are overrepresented in our sample we choose not to set a higher age limit. The results show some evidence that greater inequality increases the risk of being hospitalized among individuals who were 40 or older when immigrating. Two out of

\footnotetext{
${ }^{20}$ This is possibly due to the fact that we analyze a period in which Sweden was hit by a major recession following a large banking crisis. Note also that we adopt a slightly conservative approach when using the overall standard deviation change in inequality to evaluate the size of the estimates because the variation used in our regressions to identify the parameter of interest is in fact the within-municipality variation, which is only 40 percent of that of the overall variation (see Table A.2).

${ }^{21}$ OECD (2007) reports that Sweden is one of the countries with the largest native-immigrant gaps in the labor market.
} 
three point estimates are statistically significant at the 5 percent level. These coefficients imply about a 9 percent increase in the probability of being admitted to hospital. As described in the next subsection, these results are not robust to using alternative objective measures of health.

Our data also allows us to separately investigate different diagnoses. We focus on some common illnesses which have been highlighted in the past literature to likely be linked to inequality (see e.g. Wilkinson 1996; 1997). Table 3 presents the results from this analysis. There is no statistically significant effect for any of the outcomes. Since the incidence of each diagnosis is low the precision of the estimates is not as good as in Table 2. It is however interesting that the sign on the coefficients actually is negative in about half of the cases. This is the kind of pattern one would expect to find if the estimates were generated by a random process.

\subsection{Sensitivity checks and additional analyses}

Table 4 present results from several robustness checks and provides some additional results. Panel A asks whether the results are sensitive to how we specified our regression model. One concern is that, even though we have plausibly exogenous variation in initial location, inequality could be correlated with other properties of the municipality that also affect health. It is however important to note that our baseline model controls for all permanent differences across municipalities that may correlate with inequality and health. This raises the question if changing regional characteristics may confound our estimates. To assess whether the results are likely to be driven by unobserved evolving local factors we drop our set of time-varying municipal covariates: population size, unemployment rate and the share university educated. Presumably 
these variables are among those most strongly linked to inequality and health. Is

therefore interesting that our baseline results (in Panel A in Table 2) remain stable when dropping these controls.

Table 3 OLS estimates of the effect of initial inequality on the probability of being hospitalized in five years after arrival by type of diagnosis

\begin{tabular}{|c|c|c|c|}
\hline & \multicolumn{3}{|c|}{ Inequality measure } \\
\hline Dependent variable $=1$ if diagnosed with & $\begin{array}{l}\text { Gini } \\
\text { (1) }\end{array}$ & $\begin{array}{l}\text { CV } \\
\text { (2) }\end{array}$ & $\begin{array}{c}\log \\
(\mathrm{P} 90 / \mathrm{P} 10) \\
(3)\end{array}$ \\
\hline Respiratory diseases (Outcome mean .026) & $\begin{array}{c}-.079 \\
(.083) \\
{[-9.4 \%]}\end{array}$ & $\begin{array}{l}-.002 \\
(.002) \\
{[-3 \%]}\end{array}$ & $\begin{array}{c}-.016 \\
(.018) \\
{[-8.7 \%]}\end{array}$ \\
\hline Mental disorders (Outcome mean .027) & $\begin{array}{c}.098 \\
(.097) \\
{[11.3 \%]}\end{array}$ & $\begin{array}{c}.005 \\
(.003) \\
{[7.2 \%]}\end{array}$ & $\begin{array}{c}.014 \\
(.022) \\
{[7.4 \%]}\end{array}$ \\
\hline Cancer (Outcome mean .016) & $\begin{array}{c}-.014 \\
(.079) \\
{[-2.7 \%]}\end{array}$ & $\begin{array}{c}-.002 \\
(.001) \\
{[-4.8 \%]}\end{array}$ & $\begin{array}{c}.015 \\
(.016) \\
{[13.3 \%]}\end{array}$ \\
\hline Ischemic heart diseases (Outcome mean .009) & $\begin{array}{c}.071 \\
(.051) \\
{[24.5 \%]}\end{array}$ & $\begin{array}{c}.001 \\
(.002) \\
{[4.3 \%]}\end{array}$ & $\begin{array}{c}.013 \\
(.011) \\
{[20.5 \%]}\end{array}$ \\
\hline Diabetes (Outcome mean .006) & $\begin{array}{c}-.032 \\
(.051) \\
{[-16.5 \%]}\end{array}$ & $\begin{array}{c}.002 \\
(.002) \\
{[12.9 \%]}\end{array}$ & $\begin{array}{c}-.006 \\
(.010) \\
{[-14.2 \%]}\end{array}$ \\
\hline $\begin{array}{l}\text { Municipality FE:s } \\
\text { Contry of origin FE:s } \\
\text { Year of arrival FE:s }\end{array}$ & $\begin{array}{l}\text { Yes } \\
\text { Yes } \\
\text { Yes }\end{array}$ & $\begin{array}{l}\text { Yes } \\
\text { Yes } \\
\text { Yes }\end{array}$ & $\begin{array}{l}\text { Yes } \\
\text { Yes } \\
\text { Yes }\end{array}$ \\
\hline \multicolumn{4}{|c|}{$\begin{array}{l}\text { Notes: Each cell represents a separate regression. Inequality is measured at the (initial) municipality } \\
\text { level using disposable income. The sample consists of refugees age } 25-60 \text { at arrival who immigrated } \\
\text { 1990-1994 (N=65,595). The regressions control with dummies for: age at immigration, educational } \\
\text { attainment (five levels), gender, marital status, missing values, and linearly for: disposable income (and } \\
\text { its square) and family size. The regressions include municipality level controls for the unemployment } \\
\text { rate, population size, and share of university educated; all entered in logs. Standard errors clustered at } \\
\text { the municipality level in parentheses. } * *=\text { significant at } 5 \% \text { level: } *=\text { significant at } 10 \% \text { level. }\end{array}$} \\
\hline
\end{tabular}

Another way to investigate whether the results are sensitive to unobserved local shocks is to include county-by-year fixed effects in the regressions. This approach absorbs shocks that affect all individuals in a given county similarly; for instance, 
changes in the quality of the regional health care. ${ }^{22}$ The strategy is quite demanding in the sense that it only relies on variation across municipalities within counties to identify the effect of inequality. It is reassuring to find that our results are stable when adding county-by-year fixed effects to our baseline model.

We also investigated whether there is a non-linear relationship between inequality and health by adding squared terms to our regressions. As we can see in Panel B, there is no evidence of such relationship.

As discussed earlier, one potential concern is that we only have health measures for individuals who were admitted to hospital. If there is systematic selection into medical care based on local inequality our results may be biased. Fortunately, the institutional setting is such that this problem may not be so severe, especially considering that we have access to detailed data. In the Swedish health care system the local county councils shall provide its residents with equal access to medical care to very low fees. This is likely to weaken the financial incentives for selection into medical care.

Moreover, our estimation strategy controls for most of this potential selection process. The municipality fixed effects account for permanent differences in the quality of the local health care as well as the possibility that the inhabitants may be more or less likely to seek medical care. Origin group fixed effects control for potential discrimination by the health care system towards specific ethnic groups in addition to any group specific differences in the propensity to seek medical care. The year fixed effects absorb annual shocks that are common for all individuals and correlates with health and inequality.

\footnotetext{
${ }^{22}$ Note that we cannot include municipality by year fixed effects as this would remove the variation used to identify our parameter of interest.
} 
Table 4 Sensitivity checks and additional analyses (OLS estimates)

\begin{tabular}{|c|c|c|c|}
\hline & \multicolumn{3}{|c|}{ Inequality measure } \\
\hline & $\begin{array}{l}\text { Gini } \\
(1)\end{array}$ & $\begin{array}{l}\text { CV } \\
(2)\end{array}$ & $\begin{array}{c}\log (\mathrm{P} 90 / \mathrm{P} 10) \\
(3)\end{array}$ \\
\hline Baseline estimate (as in Panel A of Table 2) & $\begin{array}{l}.221 \\
(.245)\end{array}$ & $\begin{array}{c}.001 \\
(.007)\end{array}$ & $\begin{array}{l}.049 \\
(.060)\end{array}$ \\
\hline A. Change in specification & & & \\
\hline Removing regional level controls & $\begin{array}{l}.139 \\
(.244)\end{array}$ & $\begin{array}{l}.001 \\
(.007)\end{array}$ & $\begin{array}{l}.025 \\
(.056)\end{array}$ \\
\hline Including county $\times$ year FE:s & $\begin{array}{l}.140 \\
(.324)\end{array}$ & $\begin{array}{l}-.001 \\
(.007)\end{array}$ & $\begin{array}{l}-.004 \\
(.089)\end{array}$ \\
\hline B. Non-linear effects & & & \\
\hline Inequality & $\begin{array}{l}.098 \\
(.770)\end{array}$ & $\begin{array}{l}-.001 \\
(.015)\end{array}$ & $\begin{array}{l}-.128 \\
(.294)\end{array}$ \\
\hline Inequality squared & $\begin{array}{l}-.207 \\
(1.165)\end{array}$ & $\begin{array}{l}.000 \\
(.004)\end{array}$ & $\begin{array}{l}.071 \\
(.113)\end{array}$ \\
\hline C. Change in outcome & & & \\
\hline $\begin{array}{l}\operatorname{Pr}(\text { Long-term sick leave in year five after } \\
\text { arrival) (Outcome mean .059) } \\
\text { Pr(Died in five years after arrival) } \\
\text { (Outcome mean .008) } \\
\text { Average number of days hospitalized } \\
\text { (Outcome mean 3.51) }\end{array}$ & $\begin{array}{l}.060 \\
(.153) \\
-.009 \\
(.048) \\
-16.53 \\
(22.71)\end{array}$ & $\begin{array}{l}.006 \\
(.005) \\
.000 \\
(.001) \\
.391 \\
(.489)\end{array}$ & $\begin{array}{l}-.034 \\
(.043) \\
.000 \\
(.010) \\
-5.56 \\
(5.89)\end{array}$ \\
\hline D. Additional results & & & \\
\hline Inequality measured at the parish level & $\begin{array}{l}.220 \\
(.203)\end{array}$ & $\begin{array}{l}.009 \\
(.007)\end{array}$ & $\begin{array}{l}.013 \\
(.018)\end{array}$ \\
\hline Inequality measured at the county level & $\begin{array}{l}.556 \\
(.465)\end{array}$ & $\begin{array}{l}.012 \\
(.012)\end{array}$ & $\begin{array}{l}.137 \\
(.115)\end{array}$ \\
\hline Measuring inequality using earnings & $\begin{array}{l}.211 \\
(.260)\end{array}$ & $\begin{array}{l}.021 \\
(.035)\end{array}$ & $\begin{array}{c}-.229 * * \\
(.050)\end{array}$ \\
\hline E. Assessing external validity & & & \\
\hline $\begin{array}{l}\text { Origin region inequality } \geq \text { placement area } \\
\text { ineq. } \\
(\mathrm{N}=64,593)\end{array}$ & $\begin{array}{l}.302 \\
(.260)\end{array}$ & $\begin{array}{c}.002 \\
(.007)\end{array}$ & $\begin{array}{l}.063 \\
(.063)\end{array}$ \\
\hline $\begin{array}{l}\text { Origin region inequality }<\text { placement area } \\
\text { ineq. } \\
(\mathrm{N}=1,002)\end{array}$ & $\begin{array}{l}-2.114 \\
(2.264)\end{array}$ & $\begin{array}{l}-.020 \\
(.054)\end{array}$ & $\begin{array}{l}-.134 \\
(.383)\end{array}$ \\
\hline Municipality FE:s & Yes & Yes & Yes \\
\hline Contry of origin FE:s & Yes & Yes & Yes \\
\hline Year of arrival FE:s & Yes & Yes & Yes \\
\hline
\end{tabular}

Notes: Inequality is measured at the (initial) municipality level using disposable income. The sample consists of refugees aged 25-60 at arrival who immigrated 1990-1994 (N=65,595). The regressions control with dummies for: age at immigration, educational attainment (five levels), gender, marital status, missing values, and linearly for: disposable income (and its square) and family size. The regressions include municipality level controls for the unemployment rate, population size, and share of university educated; all entered in logs. Standard errors clustered at the municipality level in parentheses. ${ }^{*} *$ significant at $5 \%$ level; $*=$ significant at $10 \%$ level. 
Even though we believe that this is a rather convincing way of dealing with the potential problem one could still be concerned that there may be systematic selection into medical care based on unobserved local shocks. It is therefore reassuring that our analysis in Panel A showed that the estimates are not sensitive to controlling for annual shocks at the county level. Since Swedish health care policy is run at the county level this finding suggests that such selection is not likely to be a problem. ${ }^{23}$

To further show that selection into health care is no cause of concern we use two alternative health indicators that are less likely to be plagued by this potential problem. The first is the probability of taking long-term sick leave (more than 13 days). Sick leave is not a perfect proxy for health since there could also be other factors influencing sick leave, for instance social norms (see e.g. Hesselius, Johansson and Nilsson 2009). Nevertheless, in order for an individual in Sweden to receive sick pay it is necessary to see a doctor on the seventh day of job absence. Since a doctor's certificate is required it is reasonable to treat sick leave as a health indicator. And because an individual has economic incentives to go to the doctor to get the certificate it is less likely (s)he neglects visiting a physician in the case of illness. We have information on sick leave starting only in 1993. For that reason we cannot observe the outcome over a five year period as we have done so far. Instead we investigate the effect of initial inequality on the probability of taking out sick-leave in year five after arrival. The results in Panel C show no statistically significant effect of inequality on the probability of taking sick leave. These results support our earlier findings.

\footnotetext{
${ }^{23}$ In this context it is worth stressing again that we condition on own income in the regressions, which means that we effectively control for the risk that individuals with lower income may be less likely to go to the doctor.
} 
Mortality is a measure of health that is not subject to decisions made by physicians or patients. For some types of chronic diseases an individual will die irrespective of the treatment received. Because of this mortality represents an alternative outcome that is not biased by selection into health care. We define mortality as the probability of dying in five years after arrival. Also for this outcome we find no statistically significant effect of inequality. Note however that the estimates are imprecise.

We also experimented with using the average number of days admitted to hospital as the dependent variable. One issue is that we may lose valuable information by only examining health at the extensive margin. Based on our results it is evident that there is no statistically significant effect of inequality on the number of days hospitalized.

Previous studies have raised the question what geographic level inequality should be measured for (e.g. Deaton 2003). To examine whether our results are sensitive to the level of aggregation we experimented with regressions in which inequality was defined at the county or the parish level. There are 21 counties and about 2,000 parishes in Sweden. We ran the same set of regressions as in Table 2. As we can see in Panel D, the estimates for parishes closely resembles those in our base. It is also evident that the coefficients on our inequality measures are slightly bigger at the county level. Still, the difference is not large and the estimates are far from being statistically significantly different from zero.

Recall that we use disposable income to measure inequality. Theory does however not teach us what income concept should be used. It is possible that social status is more strongly linked to income from work. We investigated this by re- 
estimating our models using gross labor earnings. It turns out that the coefficients for the Gini and the Coefficient of Variation are close to identical to our baseline results. There is however a significant negative estimate for the (log) 90/10 percentile income ratio. We do not put so much weight on this odd finding as we are testing multiple hypotheses and therefore are bound to find some unusual estimates.

Although our results are likely to be internally valid, it is important to bear in mind that our conclusions need not hold in other populations. It is for instance possible that the level of inequality that refugees face in Sweden is substantially lower than what they previously have been exposed to in their country of origin. They may for that reason not respond to the inequality exposed to in Sweden in the same way as other groups. To address this issue, we collected data on the Gini coefficient in each country of origin. ${ }^{24}$ We then stratified our sample into two groups: one in which the individuals were placed in municipalities with lower inequality relative to their origin and one in which the inequality in the assigned municipality was higher than in their origin. If we find that inequality does not matter for health in the former group but has an adverse impact in the latter group then we should be concerned that the levels of inequality experienced in the origin regions may have been too large for us to detect any effects.

Our results shown in Panel E however reveal no significant impact in either of the two groups. For the group that experienced higher inequality in Sweden the sign of the coefficients is actually negative. We therefore conclude that our findings are likely to hold irrespective of the level of inequality that the individuals previously have been exposed to.

\footnotetext{
${ }^{24}$ The data are publically available from the CIA World Factbook. (https://www.cia.gov/library/publications/the-world-factbook/rankorder/2172rank.html). Note that since there is limited information on inequality in the years preceding the placement policy we instead used data for the latest year it was available to proxy for inequality in earlier years.
} 
A related objection is that it may take some time for newly arrived refugees to learn about the nature of inequality in their municipality of residence. The next subsection provides evidence on this issue.

Last, since we found indications that older refugees' health deteriorates when being assigned to an area with greater income inequality we investigated the robustness of these results to the alternative measures of health that are available to us. It turns out that there is no statistically significant effect of income inequality either on mortality or sickness absenteeism (results available upon request).

\subsection{Estimating the effect of long-term exposure to inequality}

So far, the aim of this paper has been to estimate the "reduced form" (or intention to treat) effect on health of inequality in the initial area to which a refugee was placed. This parameter is especially important for policy makers trying to weigh costs and benefits of similar settlement policies. To the extent that initial inequality provides a good proxy for individuals' actual exposure over a longer period our estimates also incorporate the impact of long-term exposure. Of course, this is only true as long as individuals do not change residential area over time. In this subsection we provide evidence of the effect on health of more long-term exposure to inequality. This is particularly relevant in our context since it may take some time for refugees to learn about the level of inequality they are exposed to in their community, which would suggest that our results need not be representative for other groups of the population. We are interested in estimating the following regression model

(2) Hospitalized Hkt $=\mu+\theta \overline{\text { Inequality }}_{i}+\rho^{\prime} X_{i}+\omega^{\prime} Z_{k t}+$ origin $_{j}+$ muni $_{k}+$ year $_{t}+v_{i k t}$. 
The only difference between this model and equation (1) is that inequality is measured as an average over several years. To be specific, for each individual we computed her actual exposure to inequality over a five year period after arrival by averaging the level of inequality of the municipality of residence each year. As before, the outcome of interest is the probability of being hospitalized in five years following immigration. Since long-term exposure to inequality is endogenous we instrument for this variable using the inequality level in the assigned municipality. As the institutional setup makes initial inequality exogenously determined (conditional on individual characteristics) it serves as a valid instrument. ${ }^{25}$

Table 5 presents our instrumental variable (IV) estimates. As is common in IV analyses the statistical precision is rather poor so we are no longer able to rule out large effects of inequality on health. If instead we focus on the point estimates we can see that a one standard deviation increase in inequality raises the probability of being hospitalized in the full sample by between 1.1 and 6.2 percent depending of the inequality measure used. ${ }^{26} 27$ The estimates are similar to those in our main estimations. Also when looking at different subgroups the IV estimates resembles our reduced form estimates. This is natural since the first-stage relationships are quite strong. For example, for the total sample the coefficient of the instrument is just below .4. The

\footnotetext{
${ }^{25}$ Our instrumental variables strategy is identical to the one used by Kling, Liebman and Katz (2007) and Votruba and Kling (2004) when analyzing the impact of neighborhood conditions in the MTO and the Gautreaux projects and to the previous studies using the same policy to analyze the importance of neighborhood effects for refugees (see e.g. Edin, Fredriksson and Åslund 2003; Åslund et al. 2011). ${ }^{26}$ When evaluating the size of the IV estimates we use the individual level variation in inequality.

${ }^{27}$ Note that, in general, there need not be any relationship between significance in the reduced form and significance for IV estimates. This is shown formally by Lochner and Moretti (2004). The reason is that the reduced form residual is the sum of the first stage residual and the outcome equation residual. One should expect larger standard errors for reduced form estimates than IV estimates if the two residuals are positively correlated. From a theoretical point of view it is not certain what sign of the correlation one should expect between the two residuals.
} 
statistical precision of the first-stage relationship is extremely good and discards any potential concerns of weak instruments. ${ }^{28}$

Table 5 IV estimates of the effect of long-term exposure to inequality on the probability of being hospitalized in five years after arrival

\begin{tabular}{|c|c|c|c|}
\hline \multirow[b]{2}{*}{ Sample } & \multicolumn{3}{|c|}{ Inequality measure } \\
\hline & $\begin{array}{l}\text { Gini } \\
(1) \\
\end{array}$ & $\begin{array}{l}\mathrm{CV} \\
(2)\end{array}$ & $\begin{array}{c}\log (\mathrm{P} 90 / \\
\mathrm{P} 10) \\
(3)\end{array}$ \\
\hline $\begin{array}{l}\text { A. Total sample } \\
(\mathrm{N}=65,595 \text {; Outcome mean .282) }\end{array}$ & $\begin{array}{l}.569 \\
(.611) \\
{[6.2 \%]}\end{array}$ & $\begin{array}{c}.006 \\
(.033) \\
{[1.1 \%]}\end{array}$ & $\begin{array}{c}.124 \\
(.151) \\
{[6.2 \%]}\end{array}$ \\
\hline B. Education & & & \\
\hline University ( $\mathrm{N}=17,988$; Outcome mean .244) & $\begin{array}{c}.391 \\
(1.325) \\
{[5 \%]}\end{array}$ & $\begin{array}{l}-.008 \\
(.082) \\
{[-1.6 \%]}\end{array}$ & $\begin{array}{c}.235 \\
(.275) \\
{[13.7 \%]}\end{array}$ \\
\hline $\begin{array}{l}\text { High school or less }(\mathrm{N}=47,607 \text {; Outcome mean } \\
.297)\end{array}$ & $\begin{array}{c}.560 \\
(.698) \\
{[5.8 \%]}\end{array}$ & $\begin{array}{l}.004 \\
(.038) \\
{[.6 \%]}\end{array}$ & $\begin{array}{l}.093 \\
(.163) \\
{[4.4 \%]}\end{array}$ \\
\hline C. Gender & & & \\
\hline Females ( $\mathrm{N}=30,567$; Outcome mean .315) & $\begin{array}{c}.247 \\
(1.010) \\
{[2.4 \%]}\end{array}$ & $\begin{array}{l}-.034 \\
(.055) \\
{[-5.2 \%]}\end{array}$ & $\begin{array}{l}.243 \\
(.216) \\
{[11 \%]}\end{array}$ \\
\hline Males (N=35,028; Outcome mean .254) & $\begin{array}{l}.782 \\
(.770) \\
{[9.5 \%]}\end{array}$ & $\begin{array}{l}.039 \\
(.049) \\
{[7.5 \%]}\end{array}$ & $\begin{array}{l}-.023 \\
(.186) \\
{[-1.3 \%]}\end{array}$ \\
\hline D. Age at immigration & & & \\
\hline Less than $40(\mathrm{~N}=47,784$; Outcome mean .259) & $\begin{array}{l}-.064 \\
(.700) \\
{[-.8 \%]}\end{array}$ & $\begin{array}{l}-.032 \\
(.049) \\
{[-5.9 \%]}\end{array}$ & $\begin{array}{l}-.042 \\
(.173) \\
{[-2.3 \%]}\end{array}$ \\
\hline At least $40(\mathrm{~N}=17,811$; Outcome mean .344) & $\begin{array}{l}2.324 * \\
(1.196) \\
{[20.9 \%]}\end{array}$ & $\begin{array}{c}.130 \\
(.094) \\
{[18.4 \%]}\end{array}$ & $\begin{array}{l}.547 * * \\
(.276) \\
{[22.6 \%]}\end{array}$ \\
\hline Municipality FE:s & Yes & Yes & Yes \\
\hline Contry of origin FE:s & Yes & Yes & Yes \\
\hline Year of arrival FE:s & Yes & Yes & Yes \\
\hline
\end{tabular}

Notes: Each cell represents a separate regression. The endogenous variable is an individual's average exposure to inequality starting in the year of arrival and ending five years later. The excluded instrument is the assigned inequality level. Inequality is measured at the municipality level using disposable income. The sample consists of refugees aged 25-60 at arrival who immigrated 1990-1994. The regressions control with dummies for: age at immigration, educational attainment (five levels), gender, marital status, missing values, and linearly for: disposable income (and its square) and family size. The regressions include municipality level controls for the unemployment rate, population size, and share of university educated; all entered in logs. Standard errors clustered at the municipality level in parentheses. ${ }^{* *}=$ significant at $5 \%$ level; * = significant at $10 \%$ level.

\footnotetext{
${ }^{28}$ All estimates are available from the authors upon request.
} 
Note that our IV approach requires the exclusion restriction that initial exposure has no direct effect on health other than through average exposure. If initial exposure to inequality affects the dynamic accumulation of health capital the IV strategy is no longer valid (see e.g. Heckman 2007 on this point). ${ }^{29}$ It is important to remember this when interpreting the results from this exercise.

\section{Concluding remarks}

This paper examines the effect of income inequality on health outcomes for a sample of refugees. Investigations of this kind are complicated due to the requirements of high quality individual level data and methods to account for non-random residential sorting. We address these problems using rich administrative hospitalization data together with a settlement policy where Swedish authorities distributed newly arrived refugee immigrants across localities. Overall, our results show no statistically significant effect of income inequality on health. The estimates are precise enough to discard large effects. Our findings parallel those in recent observational studies (e.g. Jones and Wildman 2008). We do however find an adverse impact on health for older individuals. Yet, the magnitude of this effect is not large and the results are not sensitive to the measure of health used.

It is of course relevant to ask whether our results are an artifact of the specific context in which our analysis is performed. In comparison with other countries, Sweden has traditionally been considered as an egalitarian country (see e.g. Aaberge et al. 2002). The country has an extensive welfare state, which among other things,

\footnotetext{
${ }^{29}$ On the other hand, if one believes that it takes time for individuals to learn about the level of municipality inequality level that they are exposed to, then initial exposure to inequality should have no direct effect on health.
} 
encompasses publicly financed health care, schools, pensions, old age care, and social services. There are also many different forms of income support. Could this institutional setting compensate for the potential detrimental effect of inequality on health?

In this respect it is important to remember that while other studies focus on the total population within a community, our study is the first one to explicitly examine a group of socioeconomically disadvantaged individuals. Many of the theoretical predictions suggest that less affluent groups should be more hurt. It is therefore notable that we find so limited evidence that inequality affects health. Equally noteworthy is that there is no effect of inequality on health even when studying individuals with worse socioeconomic status (i.e. lower education) within this underprivileged group of refugees.

Still, even though the results are internally valid it is important to bear in mind that refugees represent a special group of individuals which might limit the scope of generalizing the results to a larger population. One issue for instance is that income inequality in the country of origin might have been considerably larger than the level of inequality experienced in Sweden. It is not implausible to think that individuals that have been subject to high levels of inequality might not respond to the relatively lower levels they are exposed to in Sweden. A related issue is that refugees at least initially may not compare themselves to other members in their municipality of residence and that it may take some time for them to observe the level of inequality in their residential area. Although our results suggest otherwise we cannot rule out these possibilities.

It is also conceivable that inequality does not matter in a setting where equality of opportunity is large. Compared to the US, for instance, Sweden has significantly 
higher rate of intergenerational mobility (see e.g. Björklund and Jäntti 1997). ${ }^{30}$

Although this undeniably is an interesting question to explore it is one we leave for future research to explore.

${ }^{30}$ There is evidence that the intergenerational transmission of education among immigrants in Sweden is only slightly lower compared to natives (Niknami 2010). 


\section{References}

Aaberge, R., Björklund, A., Jäntti, M. Palme, M., Pedersen, P., Smith, N. and T. Wennemo (2002), "Income Inequality and Income Mobility in the Scandinavian Countries Compared to the United States", Review of Income and Wealth, 48(4): 443469.

Åslund, O., Edin, P-A., Fredriksson, P. and H. Grönqvist (2011), "Peers, Neighborhoods and Immigrant Student Achievement: Evidence from a Placement Policy", American Economic Journal: Applied Economics, 3(2): 67-95.

Åslund, O. and P. Fredriksson (2009), "Ethnic Enclaves and Welfare Culture-QuasiExperimental Evidence", Journal of Human Resources, 44(3): 799-825.

Åslund, O. and D-O. Rooth (2007), "Do when and where matter? Initial labor market conditions and immigrant earnings“, Economic Journal, 117(518): 422-448.

Atkinson, A. (1970), "On the Measurement of Inequality", Journal of Economic Theory, 2(3): 244-263.

Bertrand, M., Duflo, E. and S. Mullainathan (2004), "How Much Should We Trust Differences-in-Differences Estimates, Quarterly Journal of Economics, 119(1): 249275.

Bertrand, M., Luttmer, E. and S. Mullainathan (2000), "Network Effects and Welfare Cultures", Quarterly Journal of Economics, 115(3): 1019-1055.

Björklund, A. and M. Jäntti (1997), "Intergenerational Income Mobility in Sweden Compared to the United States", American Economic Review, 87(5): 1009-1018.

Borevi, K. and G. Myrberg (2010), "Välfärdsstaten och de nyanlända: En flyktingplaceringspolitisk probleminventering", MIN Working papers series no. 10:3.

Cutler, D. and A. Lleras-Muney (2010), "Understanding Health Differences by Education", Journal of Health Economics, 29(1): 1-28.

Cutler, D., Lleras-Muney, A. and T. Vogl (2010), "Socioeconomic Status and Health: Dimensions and Mechanisms", forthcoming in the Oxford Handbook of Health Economics.

Deaton, A. (2001), "Relative deprivation, income inequality and mortality", CHW Working Paper No. 6, Princeton University.

Deaton, A. (2003), "Health, Inequality, and Economic Development", Journal of Economic Literature, 41(1): 113-158.

Deaton, A. and D. Lubotsky (2003), "Mortality, inequality and race in American cities and states", Social Science \& Medicine, 56(6):1139-1153. 
Edin P-A., Fredriksson, P. and O. Åslund (2003), "Ethnic enclaves and the economic success of immigrants: evidence from a natural experiment", Quarterly Journal of Economics, 118(1): 329-357.

Eibner, C. and W. Evans (2005), "Relative Deprivation, Poor Health Habits and Mortality", Journal of Human Resources, 40(3): 591-620.

Englund, P. (1999), "The Swedish Banking Crisis - Roots and Consequences", Oxford Review of Economic Policy, 15(3): 80-97.

Fiscella, K. and P. Franks (1997), "Poverty or income inequality as predictor of mortality: Longitudinal cohort study", British Medical Journal, 314(7096): 17241727.

Gerdtham, U. and M. Johannesson (2004), “Absolute Income, Relative Income, Income Inequality, and Mortality", Journal of Human Resources, 39(1): 228-247.

Gottschalk, P. and T. Smeeding (2000), "Empirical evidence on income inequality in industrialized countries", in: A Atkinson and F. Bourguignon (eds.), Handbook of Income Distribution, ed. 1, Vol 1, Chapter 5, pp. 261-307 Cambridge Elsevier.

Gravelle, H., Wildman, J. and M. Sutton (2002), "Income, Income Inequality and Health: What Can We Learn from the Aggregate Data?", Social Science and Medicine, 54(4): 577-589.

Gravelle H., and M. Sutton (2009), "Income, relative income, and self-reported health in Britain 1979-2000", Health Economics, 18(2):125-45.

Grönqvist, H. (2009), "Segregation and Health: Evidence from a Settlement Policy", manuscript (Sweden Institute for Social Research).

Heckman, J. (2007), "The Technology and Neuroscience of Capacity Formation”, Proceedings of the National Academy of Sciences (PNAS) 104(33): 13250-13255.

Hesselius, P., Johansson, P. and P. Nilsson (2009), "Sick of Your Colleagues' Absence?", Journal of the European Economic Association, 17(2-3): 583-594.

Jones, A. and J. Wildman (2008), "Health, Income and Relative Deprivation: Evidence from the BHPS", Journal of Health Economics, 27(2): 308-324.

Judge, K., Mulligan, J. and M. Benzeval (1998), "Income Inequality and Population Health", Social Science and Medicine, 46(4-5): 567-579.

Kaplan, G., Pamuk, E., Lynch, J., Cohen, R. and J. Balfour (1996), "Inequality in income and mortality in the United States: analysis of mortality and potential pathways", British Medical Journal, 312(7037): 999-1003. 
Kawachi, I., Kennedy, B., Lochner, K. and D. Prothrow-Smith (1997), "Social capital, income inequality and mortality", American Journal of Public Health, 87(9): 14911498.

Kling, J. and M. Votruba (2004), "Effects of Neighborhood Characteristics on the Mortality of Black Male Youth: Evidence from Gautreaux", Working-Paper 491, Industrial Relations Section, Princeton University.

Kling, J., Liebman J. and L. Katz (2007), "Experimental Analysis of Neighborhood Effects", Econometrica, 75(1): 83-119.

Krueger, A. (2004), "Inequality, Too Much of a Good Thing", in J. Heckman and A. Krueger (eds.) Inequality in American: What Role for Human Capital Policies, Cambridge, MA: MIT Press, pp. 1-75.

Leigh, A. and C. Jencks (2007), "Inequality and Mortality: Long-Run Evidence from a Panel of Countries", Journal of Health Economics, 26(1): 1-24.

Leigh, A., Jencks, C. and T. Smeeding (2009), "Health and Inequality", forthcoming in Handbook of Economic Inequality.

Lochner, K., Pamuk, E., Makuc, D., Kennedy, B. and I. Kawachi (2001), "State-Level Income Inequality and Individual Mortality Risk: A Prospective, Multilevel Study", American Journal of Public Health, 91(3): 385-391.

Lochner, L. and E. Moretti (2004), "The Effect of Education on Crime: Evidence from Prison Inmates, Arrests, and Self-Reports", American Economic Review, 94(1): 155189.

Lorgelly, P.K. and J. Lindley (2008), "What is the relationship between income inequality and health? Evidence from the BHPS", Health Economics 17(2): 249-265.

Loue, S. (1998), Handbook of Immigrant Health, New York Springer Publishing.

Lundh, C., Bennich-Björkman, L., Ohlsson, R., Pedersen, P. and D-O. Rooth (2002), Arbete var god dröj, Välfärdspolitiska rådets rapport 2002.

Stockholm: SNS förlag.

Lynch, J., Kaplan, G., Pamuk, E., Cohen, R., Heck, K., Balfour J. and H. Yen (1998), "Income inequality and mortality in metropolitan areas of the United States", American Journal of Public Health, 88(7): 1074-1080.

Mangyo, E. and A. Park (2011), "Relative Deprivation and Health: Which Reference Groups Matter?", Journal of Human Resources 46(3): 459-481.

Marmot, M., Smith, G., Stansfeld, S., Patel, C., Norht, F., Head, J., White, I., Brunner, E. and A. Feeney (1991), "Health inequalities among British Civil Servants: The Whitehall II Study”, Lancet, 337(8754): 1387-1393. 
Mellor, J. and J. Milyo (2002), "Income Inequality and Health Status in the United States: Evidence from the Current Population Survey", Journal of Human Resources, 37(3): 510-539.

Miller, D. (2001), "Income Inequality and Mortality in the US: Aggregated Data and Micro Relationships", Unpublished manuscript, Department of Economics, University of

California, Berkeley.

Miller, D. and C. Paxon (2006), "Relative Income, Race, and Mortality", Journal of Health Economics, 25(5): 979-1003.

Niknami, S. (2010), "Intergenerational Transmission of Education Among Immigrant Mothers and their Daughters in Sweden", SOFI Working Paper No. 2010/07.

OECD (2011), Divided we Stand: Why Inequality Keeps Rising, OECD Publishing

OECD (2007), "Jobs for immigrants: Labour market integration in Australia, Denmark, Germany and Sweden", Organization for Economic Cooperation and Development.

Oreopoulos, P. (2003), "The Long-run Consequences of Growing Up in a Poor Neighborhood", Quarterly Journal of Economics, 118(4): 1533-1575.

Soobadeer, M-J. and F. LeClere (1999), "Aggregation and measurement of income inequality: effects on morbidity" Social Science and Medicine, 48(6): 733-744.

Subramanyam, M., Kawachi, I., Berkman, M. and S.J. Subramaniam (2009), "Relative Deprivation in Income and Self-Rated Health in the United States", Social Science and Medicine, 69(3): 327-334.

The Swedish Association of Local Authorities and Regions (2005), "The Swedish Health Care System in an International Context: A Comparison of Care Needs, Costs, and Outcomes".

Wagstaff A. and E. van Doorslaer (2000), "Income inequality and health: what does the literature tell us?", Annual Review of Public Health, 21: 543-567.

Waldmann, R. (1992), "Income distribution and infant mortality", Quarterly Journal of Economics, 107(4): 1283-302.

Wildman, J. (2003), "Modeling health, income and income inequality: the impact of income inequality on health and health inequality", Journal of Health Economics, 22(4): 521-538.

Wilkinson, R. (1996), Unhealthy Societies: The Affliction of Inequality, London: Routledge. 
Wilkinson, R. (1997), "Health Inequalities: Relative or Absolute Material Standards?", British Medical Journal, 314(7080): 591-595

Wilkinson, R. and K. Pickett (2006), "Income inequality and population health: A review and explanation of the evidence", Social Science and Medicine, 62(7): 17681784.

Wooldridge J. M (2010), Econometric Analysis of Cross Section and Panel Data. 2:nd ed. Cambridge MA: MIT Press. 
Table A.1 Classification of diagnoses included in the analysis

\begin{tabular}{l|l|l}
\hline \hline Type of diagnosis & ICD classification & $\begin{array}{l}\text { Common diagnoses } \\
\text { included in the category }\end{array}$ \\
\hline $\begin{array}{l}\text { Respiratory diseases } \\
\text { Mental diseases }\end{array}$ & J00-J99 & $\begin{array}{l}\text { Asthma, pneumonia } \\
\text { Psychosis }\end{array}$ \\
$\begin{array}{l}\text { Cancer } \\
\text { Ischemic heart conditions }\end{array}$ & F00-F99 & \\
Diabetes & I20-I25 & Myocardial infarction \\
\hline
\end{tabular}


Table A.2 Summary statistics for selected variables

\begin{tabular}{|c|c|c|c|c|c|}
\hline Variable & Mean & $\begin{array}{l}\text { Std. } \\
\text { dev. }\end{array}$ & $\begin{array}{c}\text { Within } \\
\text { muni. } \\
\text { std. } \\
\text { dev. }\end{array}$ & Min & Max \\
\hline Individual characteristics & & & & & \\
\hline $\begin{array}{l}\text { Hospitalized in five years after } \\
\text { arrival }\end{array}$ & .282 & .450 & & & \\
\hline Female & .466 & .499 & & & \\
\hline Married & .720 & .449 & & & \\
\hline Age at immigration & 35.74 & 8.69 & & 25 & 60 \\
\hline Number of children & 1.29 & 1.45 & & 0 & 12 \\
\hline Compulsory school & .280 & .449 & & & \\
\hline At most two years high school & .138 & .345 & & & \\
\hline At least two years high school & .256 & .437 & & & \\
\hline At most two years university & .133 & .340 & & & \\
\hline At least two years university & .172 & .378 & & & \\
\hline $\begin{array}{l}\text { (Initial) Regional } \\
\text { characteristics }\end{array}$ & & & & & \\
\hline Gini Coefficient & .244 & .031 & .012 & .185 & .500 \\
\hline Coefficient of Variation & .731 & .387 & .252 & .347 & 6.122 \\
\hline $\log (\mathrm{P} 90 / \mathrm{P} 10)$ & 1.069 & .142 & .038 & .820 & 2.019 \\
\hline
\end{tabular}

